\author{
Jakub Basista (D) \\ Uniwersytet Jagielloński, Kraków
}

\title{
GANGRAENA I REMEDIUM - O HEREZJACH I ZWYRODNIENIU RELIGIJNYM W ANGLII POŁOWY XVII W. ${ }^{1}$
}

\author{
ABSTRACT \\ Gangraena and its cure: on Heresies and Religious Perversions \\ in mid-seventeenth century England
}

The English Civil War saw an explosion in the production of printed material. Booklets, pamphlets, leaflets, and ballads of all types and covering all manner of subjects appeared in their thousands. Indeed, the number of titles printed during this period surpassed 2,000 per year. Among these we find a large category of prints denouncing religious heresy and perverse behaviors. The most elaborate of these was Thomas Edwards's Gangraena, which ran to several thousand pages in length and spanned three consecutive volumes. In this article, the author looks at various religious sects in England and aspects of their beliefs and behaviors to examine how the Restoration England of Charles II tried to cure its population of unorthodox and perverse religious ideas.

Key words: heresy, seventeenth century England, Clarendon Code, Gangraena

Słowa kluczowe: herezja, Anglia XVII w., kodeks Clarendona, Gangraena

1 Dziękuję Recenzentom za cenne uwagi zamieszczone w ich opracowaniach, które wskazały szereg niedociągnięć i nielogiczny układ całości. Wszelkie błędy i nieścisłości, które pozostały, obarczają wyłącznie autora tekstu. 
Według jednego z popularnych i dostępnych w Internecie źródeł słownikowych „gangrena" posiada trzy znaczenia i są to:

1. proces gnilny tkanek wywołany w żywym organizmie przez bakterie gnilne

2. upadek moralny, zepsucie

3. pogard. o człowieku irytującym, dokuczliwym².

W roku 1646 w Anglii ukazały się drukiem trzy dzieła, a raczej trzy tomy jednego dzieła zatytulowanego: Gangraena or a Catalogue and Discovery of many of the Errours, Heresies, Blasphemies and pernicious Practices of the Sectaries of this time, vented and acted in England in these four last yeers ${ }^{3}$. Na niezwykle żywym i bogatym rynku wydawniczym początku lat czterdziestych wieku XVII pewien pastor anglikański niejaki Thomas Edwards wydał rzeczone dzieło, w którym przedstawiał - jego zdaniem - tragiczną sytuację religijną owych czasów. O tym zresztą świadczy tytuł owej publikacji - „Gangrena, czyli katalog błędów, herezji i bluźnierstw religijnych”. Anglię początku lat czterdziestych wieku XVII miała trawić swoista gangrena (religijna) spowodowana odejściem obywateli od prawdziwej wiary, za jaką uważał anglikanizm, i pogrążenie się w dziesiątkach odstępstw, błędów i herezji czy wręcz perwersji religijnych.

W niniejszym artykule próbuję odtworzyć obraz swoistej panoramy religijnej w ówczesnym Londynie na podstawie drukowanych broszurek, książeczek i pamfletów, których swoistą kulminacją i najpełniejszym przykładem jest właśnie owa Gangraena Edwardsa. Nie ulega wątpliwości, iż sytuacja religijna - w szczególności w stolicy - wymknęła się spod jakiejkolwiek kontroli, a różnorakie sekty, grupy modlitewne, zgromadzenia religijne mnożyły się w wielkiej liczbie. Były wśród nich grupy osób w rzeczywisty sposób próbujące odnaleźć drogę do zbawienia, byli liczni reformatorzy szukający większej swobody niż proponował Kościół anglikański lub - przeciwnie - wierni pragnący większej dyscypliny i przestrzegania nakazów Starego i Nowego Testamentu, byli również różni hochsztaplerzy wykorzystujący sytuację i naiwność współmieszkańców dla sobie tylko znanych korzyści. Nie jesteśmy w stanie dzisiaj policzyć owych grup, wyodrębnić ich i zbadać działalności każdej z nich. Niektóre były mocniejsze, liczniejsze i przetrwały dłuższy okres, inne to szybko zanikające efemerydy. Owe ruchy religijne - czy też pseudoreligijne - opisywane były w różny sposób: od poważnego ujawniania ich odejścia od prawdziwej wiary po

2 Gangrena, [hasło w:] https://encyklopedia.pwn.pl/encyklopedia/gangrena.html (dostęp: 23 IV 2018).

3 Th. Edwards, Gangraena or a Catalogue and Discovery of many of the Errours, Heresies, Blasphemies and pernicious Practices of the Sectaries of this time, vented and acted in England in these four last yeers, London 1646; i e m, The Second Part of Gangraena or A fresh and further Discovery of many of the Errors, Heresies, Blasphemies and pernicious Practices of the Sectaries of this time, vented and acted in England in these four last yeers, London 1646; id e m. The third part of Gangraena. Or, A new and higher discovery of the errors, heresies, blasphemies, and insolent proceedings of the sectaries of these times; with some animadversions by way of confutation upon many of the errors and heresies named, London 1646. 
prześmiewcze, kpiące komentarze szyderców. Często mamy do czynienia li tylko z prymitywną wyliczanką możliwie dużej liczby herezji.

Autorzy opisujący zaistniałą sytuację wykazują daleko idącą wyobraźnię oraz inwencję i nie ma dla nich znaczenia, czy wśród herezji opisują rzeczywistych innowierców, odstępców od wiary, bluźnierców czy też katolików, stronnictwa Rzymu, kardynałów bądź frakcję francuską i hiszpańską (również przedstawiane jako swoiste herezje).

Jeśli spojrzymy na tę sytuację z perspektywy kościoła instytucjonalnego - Londyn, a w rzeczywistości Anglię połowy XVII w. toczył swoisty religijny proces gnilny, rzeczywisty upadek moralny i zepsucie. Sytuacja się nieco poprawiła i została w pewnym stopniu ograniczona podczas dyktatury Olivera Cromwella, ale rzeczywiste kroki organizacyjno-prawne dążące do likwidacji wszystkich grup i zgromadzeń heretyckich podjęto dopiero po restauracji Stuartów, dokładając starań, aby ów chaos i brak jakiejkolwiek kontroli zakończyć.

Celem moim jest naszkicowanie ówczesnej sytuacji w specyficzny sposób, gdyż robię to poprzez pryzmat ówczesnych druków ulotnych. Nie jest to zatem obiektywna analiza sytuacji, lecz badanie obrazu owej różnorodności religijnej w postaci, w jakiej opisywana była przez ówczesnych autorów literatury ,jarmarcznej, brukowej”. Staram się spojrzeć na ową sytuację przez pryzmat przeciętnego londyńczyka, który nie tyle znał funkcjonujące w jego otoczeniu sekty, ile czytał o nich w dosyć powszechnie rozpowszechnianej taniej literaturze - de facto sensacyjnej. Na koniec wskażę, jakie środki zaradcze zastosowane zostały po roku 1660.

Dlatego też nie próbuję nawet podjąć analizy teologicznej i doktrynalnej różnic pomiędzy poszczególnymi grupami i sektami. Nie jest moim zamiarem badanie, jak wiele owych sekt rzeczywiście istniało, jaki miały wpływ na społeczeństwo, kogo rzeczywiście można nazwać heretykiem, dysydentem czy kacerzem. Chcę zwrócić uwagę na zjawisko społeczne, które zaistniało w ówczesnej Anglii (głównie w Londynie) i które można odtworzyć, czytając ówczesne źródła, w szczególności dzieło Edwardsa, aby zastanowić się następnie, w jaki sposób próbowano walczyć z ową gangreną. Czy walka owa była skuteczna?

Gangraena Thomasa Edwardsa od wielu lat była dla naukowców podstawą do opisu sytuacji religijnej w królestwie Albionu w połowie wieku XVII. Historycy są raczej zgodni, iż przedstawione przez niego fakty są pewnym odzwierciedleniem religijnych podziałów i panującego w tej sferze chaosu ${ }^{4}$. Rzadko bierze się jednak jego słowa za bezwarunkowo

\footnotetext{
4 A. Hughes, Gangraene and the Struggle for the English Revolution, Oxford 2004, s. v-vii. Autorka w swojej pracy przedstawiła krytyczną analizę pracy Edwardsa, m.in. podkreślając, że jej celem było nie tyle zestawienie owych dziesiątków przypadków herezji i bluźnierstw, ile raczej swoista ich weryfikacja i odpowiedź na pytanie dotyczące metodologii Thomasa Edwardsa. Książka jest znakomita, aczkolwiek na nasz użytek jej najważniejsze ustalenia są mniej istotne. W pełni potwierdza ona istnienie owej „gangreny” religijnej w ówczesnej Anglii.
} 
prawdziwe i stara się je potwierdzać w innych źródłach. Dzieło to świadczy jednak o daleko posuniętym rozprężeniu dyscypliny religijnej, braku kontroli i funkcjonowania kościoła instytucjonalnego. Parlament, który skutecznie przeciwstawiał się działalności partii królewskiej, podejmował uchwały dotyczące religii, ale nie był w stanie (a być może nie chciał) zajmować się bieżącą sytuacją religijną - przynajmniej nie w pierwszej połowie lat czterdziestych. Z drugiej strony obóz królewski nie posiadał środków ani nie kontrolował dostatecznego terytorium (w szczególności Londynu), aby w sposób skuteczny egzekwować nakazy religijne. Zresztą to właśnie Karol I i jego otoczenie najdotkliwiej odczuli konsekwencje aresztowania i przetrzymywania w Tower biskupów Kościoła anglikańskiego.

Sytuacja opisywana przez Edwardsa nie była wynikiem jakichś gwałtownych turbulencji społecznych. Kształtowała się ona przez kilka lat i powstawała na podatnym gruncie uformowanym podczas rządów Karola I i jego ministra Williama Lauda, chociaż już w czasach elżbietańskich jesteśmy świadkami podziałów w Kościele anglikańskim55. Przejęcie władzy przez Jakuba w 1603 r. tworzyło pewne nadzieje na uspokojenie sytuacji, lecz nadzieje te okazały się bezzasadne ${ }^{6}$. Jakub nie tylko nie wprowadził większej tolerancji religijnej, np. dla purytanów czy też katolików ${ }^{7}$, ale wszedł w nierozwiązywalny spór z parlamentem. Z jednej strony nigdy nie zgodził się z opozycją Anglików wobec unii angielsko-szkockiej ${ }^{8}$, ale również nie godził się na kwestionowanie jego prerogatyw monarszych przez deputowanych angielskich' ${ }^{9}$ Sytuacja nie uległa polepszeniu za czasów panowania jego syna, Karola I. Król przez 11 lat nie zwoływał parlamentu, zaś kwestie religijne powierzył swojemu zaufanemu ministrowi i arcybiskupowi Canterbury - wspomnianemu Williamowi Laudowi. Tymczasem ten - jak się wydawało - kierował Kościół ku arminianizmowi, czy wręcz ku praktykom katolickim. Obok podejmowania prób wprowadzania znaczących zmian w Kościele angielskim, arcybiskup podjął kroki mające ujednolicić i połączyć religie w Anglii, Szkocji i Irlandii. Dzisiaj nikt nie ma wątpliwości, iż to właśnie próby wprowadzenia Kościoła anglikańskiego w Szkocji walnie przyczyniły się do kryzysu na Wyspach w połowie wieku XVII ${ }^{10}$.

J. B asista, Kościót elżbietański: między martyrologia a reforma, [w:] Sic Erat in Fatis. Studia i szkice historyczne dedykowane Profesorowi Bogdanowi Rokowi, red. E. Kościk, R. Żerelik, P. Badyna, F. Wolański, t. I, Toruń 2012, s. 272-282.

6 J. B asista, Jakub VI (I) Stuart w angielskiej przestrzeni religijnej, „Studia Europaea Gnesnensia” 2018, t. 18 , s. 385-406.

7 Ch.W.A. Prio r, Defining the Jacobean Church. The Politics of Religious Controversy, 1603-1625, Cambridge 2005, passim.

8 J. Basista, Anglia i Szkocja między uniami (1603-1707), [w:] Europa unii i federacji, red. K. Ślu sa rek, Kraków 2004, s. 131-140.

9 J. Basista, Koncepcja wtadzy monarszej Jakuba VI(I), [w:] Spory o państwo w dobie nowożytnej, red. Z. Anusik, Łódź 2007, s. 357-366.

10 L. Ja me s, 'This Great Firebrand.' William Laud and Scotland 1617-1645, Woodbridge 2017; J. B a s is ta, Spór wokót arminianizmu. Czy arcybiskup Laud wywotat angielska rewolucję?, [w:] Studia z dziejów kultury imentalności czasów nowożytnych, red. K. Ma t w ijow ski, B. Rok, Wrocław 1993, s. 113-124. 
Wydarzenia 1640 roku, a w szczególności powołanie przez monarchę parlamentu ${ }^{11}$, nie rozwiązały skomplikowanej sytuacji, gdyż monarcha, nie chcąc iść na kompromis z poddanymi, niemal natychmiast rozwiązał zgromadzenie. Był to tzw. Krótki Parlament. Karol I nie potrafił jednak zażegnać kryzysu bez pomocy deputowanych ${ }^{12}$ i kilka miesięcy później zwołał kolejny parlament. Tym razem formalnie funkcjonował on przez 20 lat, aż do samorozwiązania w 1660 r. Był to tzw. Długi Parlament.

Parlament wydał wiele uchwał skierowanych przeciw polityce króla, a szczególnie bezwzględnie zaatakował królewskich urzędników ${ }^{13}$. Przekonał się o tym najszybciej i najboleśniej Thomas Wentworth, pierwszy earl Strafford, a zarazem lord deputy Irlandii, który został natychmiast aresztowany i szybko stracony (12 maja 1641 r.). Do Tower powędrowało kilkunastu biskupów z arcybiskupem Williamem Laudem na czele.

Rozprężenie, brak kontroli kościelnej, brak urzędników, uwięzienie cenzorów doprowadziły do różnych, wielopłaszczyznowych skutków. Wystarczy choćby wspomnieć, że współodpowiedzialny za swoisty chaos parlament nie posiadał żadnej rzeczywistej broni w 1640 r. Następuje próba mobilizacji mieszkańców Londynu, tworzenia milicji obywatelskiej, a w dalszej perspektywie wojska. Nie to jednak jest tematem niniejszych rozważań. Zwróćmy uwagę na dwa zjawiska. Po pierwsze brak kontroli nad drukarniami (było ich w Londynie ok. 20) oraz brak cenzury doprowadzają do swoistej eksplozji produkcji publicystycznej. Bez tej rewolucji publicystyczno-drukarskiej nie byłoby zapewne trzech tomów „Gangreny” Edwardsa.

Drugim istotnym zjawiskiem było całkowite rozprężenie dyscypliny religijnej. Biskupi w Tower, niżsi urzędnicy kościelni wybierający między parlamentem a królem bądź realizujący swoje postulaty purytańskie czy też separatystyczne umożliwili tworzenie różnych, często niekonwencjonalnych i niedoktrynalnych grup religijnych. Niestety nie ma odpowiednich, bezpośrednich źródeł umożliwiających ich badanie. Twórcy i członkowie owych

11 Chodzi oczywiście o powołanie parlamentu, który zyskał w historiografii nazwę „Krótkiego”, gdyż prawie natychmiast został rozwiązany. To wydarzenie, jak i wydarzenia następnych kilkunastu lat są tłem w dużej mierze decydującym o omawianych tu sporach i rozwiązłości religijnej. Są to jednak sprawy bardzo dobrze znane (choć niekoniecznie w Polsce), przeto rezygnuję przy malowaniu owego tła z przypisów. Pojawią się, gdy będę się odnosił do źródeł lub spraw kontrowersyjnych, wzbudzających po dziś dzień dyskusję i różne interpretacje.

12 Problemy przyczyn wojen domowych bądź rewolucji (by użyć zarzuconej terminologii marksistowskiej) omawiane były wiele razy, ale za ostateczne ich podsumowanie uważa się pracę: C. Ru s s ell, The Causes of the English Civil War, Oxford 1990, s. 58-108.

13 Literatura naukowa dotycząca tych wydarzeń jest bardzo obszerna. Tutaj chciałbym zwrócić uwagę na artykut: H. Trevor-Roper, The Fast Sermons of the Long Parliament, [w:] ide m, The Crisis of the Seventeenth Century, New York 1967, s. 275-276. Autor zwraca uwagę na fakt, iż członkowie Długiego Parlamentu byli znakomicie przygotowani do obrad i mieli konkretne plany, co i jak należy zrobić. Wydaje się jednak, że nie byli w stanie przewidzieć skutków swoich decyzji ani dynamiki wydarzeń. W szczególności nie mogli wiedzieć, jakie skutki przyniesie paraliż instytucji Kościoła anglikańskiego spowodowany odpowiednimi ustawami i aresztowaniem wielu biskupów. 
grup i sekt nie musieli się rejestrować, nie płacili podatków, nie ogłaszali swoich własnych druków, a zatem zazwyczaj nie pozostawiali śladów w formie trwałych dokumentów sporządzonych przez samych siebie. Wielu z przywódców owych sekt zapewne w ogóle nie umiało czytać i pisać. Dlatego też skazani jesteśmy na takich autorów jak Thomas Edwards i ich dzieła, mając w pamięci, iż nie czytamy protokołów czy też rzetelnych sprawozdań ze spotkań owych grup, raportów policyjnych bądź prac naukowych.

Pierwszy okres kryzysu połowy wieku XVII (który trwał przez 20 lat, 1640-1660) to jeszcze próby współpracy parlamentu z Karolem I. Później monarcha opuszcza Londyn, „wznosi swoje sztandary” - jak piszą niektórzy historycy - i po 1642 r. dochodzi do wojen domowych, licznych potyczek i bitew pomiędzy wojskami rojalistycznymi i armią parlamentu. Zmagania te były specyficzne, gdyż brat walczył przeciw bratu, tereny starć ulegały dewastacji i depopulacji, podczas gdy niektóre rejony Anglii, a w szczególności Londyn, nie ucierpiały w wyniku działań wojennych. Są wsie, a nawet całe regiony, gdzie szczątkowe źródła wskazują, iż praktycznie w ogóle nie wiedziano o panującej wojnie ${ }^{14}$.

Wraz z pojawieniem się możliwości rusza masowa produkcja druków - w dużej części proparlamentarnych i propagandowych ${ }^{15}$. Pojawiają się liczne pisemka informujące o zagrożeniach ze strony papistów, jezuitów, Francuzów, Hiszpanów czy nawet stronników monarchy. Znana wcześniej antykatolicka propaganda ${ }^{16}$ wzbiera na sile i jest niezwykle urozmaicona. Już na samym początku pojawiają się również pisma i broszury informujące o sektach i herezjach ${ }^{17}$.

Już w 1641 r. ukazuje się kilkustronnicowa broszurka zatytułowana $A$ Discovery of 29 sects here in London, all of which except the first, are most divelish and damnable ${ }^{18}$. Jest to

14 J. Morrill, Revolt in the Provinces: the People of England and the Tragedies of War, 1630-1648, New York 1999 - to jedna z tych książek, w których zakwestionowano marksistowską koncepcję rewolucji i zwrócono uwagę na niezwykle skomplikowane przyczyny podejmowania takich lub innych decyzji, a także funkcjonujących postaw na angielskiej prowincji.

15 J. Peacey, Politicians and Pamphleteers, Hants 2004; idem, Print and Public Politics in the English Revolution, Cambridge 2013; J. Raymond, Pamphlets and Pamphleteering in Early Modern Britain, Cambridge 2003; J. Basista, Propaganda religijna w przededniu i pierwszych latach angielskiej wojny domowej, Kraków 2007.

16 A. Milton, Catholic and Reformed. The Roman and Protestant Churches in English Protestant Thought, 1600-1640, Cambridge 1995.

17 Nieco wcześniej, bo w 1640 r., ukazała się drukiem praca niejakiego Ephraima Pagitta pod tytułem Christionography, or the description of the multitude and sundry sorts of Christians in the world, not subject to the pope (London 1640). Jest to dzieło całkowicie inne od dwóch wcześniej wspomnianych. Przede wszystkim liczy blisko 300 stron, a więc nie jest to typowy druk ulotny, a poważna rozprawa poświęcona chrześcijanom różnych niekatolickich wyznań. Poza tym objętość i język dzieła wyraźnie sugerują, iż tym razem mamy do czynienia z dziełem, które na pewno nie było czytane w szynku i nie było znane w szczegółach przeciętnemu mieszkańcowi Wysp.

18 A Discovery of 29 sects here in London, all of which except the first, are most divelish and damnable, London 1641. 
typowy druk propagandowy, mający wzbudzać emocje, propagować strach i sensację, ani przez chwilę nie pretendując do chłodnej, teologicznej analizy zaistniałej sytuacji. Wszystkie z 29 „sekt” wymienione są na stronie tytułowej, a następnie mamy krótkie, kilkuwierszowe opisy każdej z nich. Jako pierwsza wymieniona jest „sekta” protestantów, dlatego też tytuł wskazuje, iż ta grupa jako jedyna nie jest skazana na potępienie. Po protestantach autor wylicza: purytanów, papistów, brownistów, kalwinistów, luteranów, Family of Love, mahometan, adamitów, brytanistów, arminian, socynian, tesalonian, anabaptystów, separatystów, chaldeończyków, elektrian, donatystów, Persów, antynomian, Asyryjczyków, Macedończyków, Heathens, Panończyków, saturian, junończyków, bachanalian, damasjan oraz bractwo miłości ${ }^{19}$. Broszurka jest krótka, zwięzła, pozbawiona odsyłaczy do pism teologicznych, ale również w pewnym sensie alarmująca. Te sekty - według autora - zostały odkryte tu i teraz, czyli w Londynie, w czasach druku owej broszury. Stanowią jakiś dysonans, by nie rzec zagrożenie dla ojczyzny. Tak broszura, jak i jej treść stanowią ostrzeżenie przed zaistniałym zagrożeniem dla wiary, dla społeczeństwa, dla rodzin i każdego londyńczyka.

W 1642 r. swoją listę heretyków publikuje niejaki Alexander Ross ${ }^{20}$. Pisze on o różnych rodzajach religii (sic), które „dostawszy się do wnętrzności tego królestwa” („crept into the very bowels of this Kingdome”) powodują jego wstrząs, ale przede wszystkim prowadzą do zniszczenia Kościoła i całego państwa. Sama treść broszurki nie odbiega od poprzednio omawianej - zawiera ona po kilka, maksymalnie kilkanaście linii opisu poszczególnych sekt. Treść przekazana jest jednak w nieco innej formie. Najpierw autor przedstawia krótką opinię o danej sekcie i wskazuje, co ją wyróżnia od innych, a następnie przytacza rzekomą odpowiedź przedstawiciela „prawdziwych” protestantów, mającą wykazać, jak głęboko mylą się i błądzą w swoich wierzeniach przedstawiciele danej sekty. Metoda opierania przekazu na swoistym dialogu była dosyć często stosowana w owych drukach - być może taka forma była łatwiejsza do zapamiętania i bardziej wiarygodna? Tym razem mamy do czynienia z „zaledwie” 16 grupami heretyckimi. Przytoczmy fragment dotyczący „ulubionych" przez mnie adamitów:

\section{Adamites}

The Adamites are a people which would live under no command of Magistrate or Church, they would be more Libertines and live as they list, following that place in the Scripture, Increase and multiply, and in their society they are so overcome with flesh, that they cannot pray.

19 Cechą charakterystyczną owych prostszych i skrótowych list herezji i sekt jest mnożenie i pączkowanie owych sekt. Pomimo próby wyliczenia i krótkiego ich opisu w: J. B a sis ta, Propaganda religijna..., s. 167199, do dzisiaj odnajduję opisy grup, które występowały na kartach badanych przez mnie druków i które starałem się opisać. Nie przeszkodziło to prof. J. Tazbirowi sugerować, iz przytaczając opisy poszczególnych grup, chciałem jedynie zwiększyć objętość książki.

20 Religions Lotterie, or the Churches Amazement, London 1642. W samej broszurce brak nazwiska autora, ale można je znaleźć w katalogach. 


\section{Protestantes Answer}

That this opinion is grounded on a vaine and fruitlesse foundation may be easily discerned, for

St. Paul tells us in his Epistle to the Galatians, chap.5, ver. 13 this Lesson; For Brethren though you have been called unto liberty, yet use not your liberty for an occasion to the Flesh, but to serve one another ${ }^{21}$.

Innymi słowy adamici, kierując się - według autora - zasadą „rośnijcie i rozmnażajcie się”, tak zajmują się własnym ciałem (nagością), iż nie mają czasu na modlitwę. Koncepcja ta jest odrzucona odpowiednim cytatem z listu św. Pawła do Galatów. Mówiąc krótko ani to głębokie, przenikliwe teksty, ani jakakolwiek polemika. Nie jest to również teologia czy rozważania doktrynalne. Są to teksty pisane na użytek prostych obywateli Anglii, a konkretniej Londynu. Pomimo treści i formy zawierają jednak pewien element opisu ówczesnej rzeczywistości, co jest dla nas najważniejsze. Ponadto narzucają pewną wizję owej rzeczywistości odbiorcom tychże druków.

Dwa lata później ukazuje się kolejny druk, podający tym razem 33 sekty: XXXIII Religions, sects, societies and factions of the Cavaliers now in Armes against the Parliament ${ }^{22}$. To, co zwraca natychmiastową uwagę, to zmiana tytułu i załączona lista owych grup. Otóż tym razem mamy do czynienia nie tylko z sektami, ale także z grupami i fakcjami działającymi przeciwko parlamentowi. Pojawiająca się nazwa „Cavaliers” używana była do określenia stronnictwa królewskiego i, choć nie jest to napisane explicite, można się domyślić, iż wszystkie owe grupy, sekty, herezje są charakterystyczne dla stronnictwa rojalistycznego, od dwóch lat będącego w stanie rzeczywistej wojny z wojskami i stronnictwem parlamentu. Nie dziwi zatem, iż listę otwiera „sekta” kardynałów. Pod numerem 2 znajdziemy „French faction”, zaś pod numerem 3 „Spanish faction”. Dopiero na czwartej pozycji znajduje się nazwa rzeczywistej, istniejącej sekty adamitów. Na dalszych miejscach znajdziemy również księży (Priests) jako szkodliwą grupę, ale także „szkodników” (Malignants” - jest to termin niezwykle często używany w ówczesnej literaturze na określenie przeciwników parlamentu i - w zależności od poglądów - przeciwników Kościoła angielskiego, prezbiteriańskiego bądź wręcz independentów). Co ciekawe, te grupy, które można uznać za rzeczywiście istniejące i będące grupami religijnymi, nie pokrywają się prawie w ogóle z tymi zamieszczonymi w druku z $1641 \mathrm{r}$.

Najobszerniejszym katalogiem herezji i odstępstw od prawdziwej wiary jest sporych rozmiarów Heresiography (Herezjografia) niejakiego Ephraima Pagitta ${ }^{23}$. Jest to dzieło róż-

21 Ibidem, s. $\mathrm{A}_{2 \mathrm{v}}-\mathrm{A}_{3 \mathrm{r}}$.

22 XXXIII Religions, sects, societies and factions of the Cavaliers now in Armes against the Parliament, London 1644. Jest to wydawnictwo objętościowo identyczne z wcześniejszymi, czyli ma 10 stron tekstu. Dobór owych druków jest na potrzeby niniejszych rozważań dosyć dowolny. Podobnych druków było więcej, ale są one w swojej treści i formie zbieżne i nie wnoszą do naszych rozważań nic nowego. Staram się wskazać na pewien związany z owymi drukami fenomen.

23 E. Pagitt, Heresiography, or a Description of the Heretickes and Sectaries sprung up in this latter times, London 1645. 
niące się od dotychczas wspominanych, gdyż autor podszedł do swojej księgi w sposób niezwykle systematyczny i poniekąd naukowo-teologiczny. Nie wychodzi on poza liczbę ok. 30 sekt, których nazwy przytaczane były przez innych autorów, ale poświęca każdej grupie od kilku do kilkudziesięciu stron, opisując ich rzekome korzenie, funkcjonowanie, historię, jak również główne błędy i heretyckie przekonania. Omawiane argumenty odsyłają niekiedy do Pisma Świętego lub konkretnych pisarzy i mają pewną wagę doktrynalną. W odróżnieniu od wspominanych broszurek, Pagitt podaje konkretne, religijne argumenty i ich wyjaśnienie.

Z naszego punktu widzenia dzieło owo jest znamienne z dwóch powodów. Umieszczenie poszczególnych grup w zestawieniu i ich omawianie wskazuje, iż rzeczywiście przewijały się one przez ówczesną Anglię. Mamy zapewne do czynienia z początkami lub wręcz zaawansowaną gangreną. Drugi istotny wniosek związany z książką Pagitta to stwierdzenie, iż praca ta nie mogła - ze względu na swoją objętość i treść - być powszechnie znana wśród „ludu” (pospólstwa). Dla prostych mieszkańców, chłopów czy nawet umiejących czytać rzemieślników Heresiography to nieosiągalny poziom erudycji. Ona i zawarte w niej treści - jak wspomniałem - są jednak potwierdzeniem olbrzymiego chaosu religijnego panującego w ówczesnej Anglii.

Aby poniekąd zamknąć temat liczby i mnożenia się sekt oraz herezji w ówczesnej Anglii, warto wspomnieć, iż istnieją liczne broszury i książeczki poświęcone pojedynczym grupom religijnym bądź wymieniające zaledwie kilka z nich. Nie są to opracowania naukowe czy teologiczne, a raczej typowe wydawnictwa sensacyjne zbieżne z wspomnianymi powyżej, mające na celu wzbudzenie zainteresowania, a najprawdopodobniej również strachu i pewnego zwątpienia. Są wśród nich broszurki o takich sektach, jak anabaptyści ${ }^{24}$, adamici ${ }^{25}$, antynomianie ${ }^{26}$, donatyści ${ }^{27}$, browniści ${ }^{28}$, publikanie ${ }^{29}$, dyscyplinarianie $^{30}$, papiści ${ }^{31}$, rodzina miłości ${ }^{32}$, socynianie ${ }^{33}$ i kilku, a nawet kilkunastu innych grupach. Nie oznacza to jednak, iż mamy do czynienia ze swoistą dysputą teologiczną, sporami

24 J. Taylor, A Cluster of Coxcombes, or a cinquepace of five sorts of Knaves and Fools, London 1942. The Remarkable Funeral of Cheapside Cross, London 1642, wymienia ośmiu heretyków/sekciarzy, którzy odprowadzali Cheapside Cross do grobu: „Anabaptist”, „Familist”, „Brownist”, „Adamite”, „Separatist”, „Rechabite”, „Precisian”, „Puritan”.

25 S. Yarb, A new Sect of Religion descrybed called Adamites, London 1643.

26 J. Sedg wick, Antynomianisme anatomized, London 1643.

27 J. Taylor, op. cit.

28 A Dialogue betwixt three travellers, London 1641; J. Taylo r, op. cit.

29 J. Taylor, op. cit.

30 Ibidem.

31 A Dialogue betwixt...

32 A description of the sect called the Family of Love, London 1641.

33 F. Cheynell, The Rise, Growth and Danger of Socinianisme, London 1643. 
doktrynalnymi, pewną różnorodnością dotyczącą pryncypiów, rytuałów czy rozumienia sakramentów, zbawienia bądź predestynacji. Wydaje się, iż ówcześni londyńczycy byli świadkami rosnącej anarchii życia religijnego, daleko posuniętym i niekontrolowanym permisywizmem, z postępującym i pogłębiającym się procesem zepsucia, gnicia, z gangreną dotykającą najważniejszych wartości, transcendentaliów w życiu indywidualnym i zbiorowym społeczeństwa.

Wszystkie wzmiankowane i cytowane wyżej publikacje wpisują się doskonale w pozostawiony nam opis sytuacji religijnej pióra Thomasa Edwardsa, czyli opis pomieszczony w trzytomowym dziele Gangraena. Autorem owych wolumenów był anglikański pastor o zdecydowanie radykalnych, skłaniających się ku prezbiterianizmowi poglądach - Thomas Edward $s^{34}$. Był on jednocześnie zdolnym i zaciekłym publicystą, wydającym prowokujące dzieła ${ }^{35}$, zazwyczaj niezwykle agresywne i kontrowersyjne, wskazujące błędy religijne jego adwersarzy. W swoim dziele wydanym w 1646 r., a następnie wzbogaconym o kolejne dwa tomy dodatków i uzupełnień, Edwards występuje przeciwko nadmiernej wolności religijnej panującej w Anglii i rzekomemu brakowi dyscypliny kościelnej. Thomas Edwards dobrze wiedział, o czym pisze i z kim walczy. Sam był osobą duchowną i to osobą otwarcie i dobitnie podkreślającą swoje poglądy religijne. Można je określić jako poglądy anglikańskie, lecz o skłonnościach purytańskich oraz prezbiteriańskich ${ }^{36}$. Będąc osobą oficjalnego Kościoła anglikańskiego, z chęcią widziałby wszelako dokończenie pewnych elementów reformacji - przede wszystkim likwidacji szeregu „katolickich” ceremonii i pilnowania dyscypliny poddanych. Jako osoba dosyć znana i aktywna (także w polemice pamfletowej) w latach czterdziestych XVII w. był adresatem wielu listów i informacji o sytuacji religijnej w poszczególnych parafiach i hrabstwach. Zbierał liczne dane na temat odstępstw od doktryny Kościoła, który zresztą w tym okresie był znacząco osłabiony poprzez aresztowanie prawie całej hierarchii anglikańskiej. Jak pisze autor jego biogramu w Oxford Dictionary of National Biography:

34 P.R.S. B aker, Edwards, Thomas, [w:] Oxford Dictionary of National Biography, www.oxforddnb.com/ view/10.1093/ref:odnb/9780198614128.001.0001/odnb-9780198614128-e-8556 (dostęp: 23 IV 2018).

35 Cytowane i wykorzystane w artykule dzieło nie było bynajmniej pierwszą publikacją Edwardsa. Miał na swoim koncie wcześniejsze edycje druków różnego kalibru - tak jakościowego, jak i objętościowego. Wszystkie wszelako dotyczyły kwestii wiary i były prowokujące oraz polemiczne.

36 Innymi słowy sympatyzował z osobami nawołującymi do oczyszczenia religii anglikańskiej z pozostałości katolicyzmu (puryfikacja - purytanizm) oraz skłonny był pozbyć się z Kościoła dosyć obszernej administracji. Podobne poglądy były dosyć mocno reprezentowane w parlamencie, choć nie były jeszcze dominujące i stały w opozycji do radykalizmu independentów. 
[...] był on oczywistym odbiorcą wszelkich wieści o sektach i ich praktykach, a zbierał je w celu organizacji zwycięskiego ataku przeciw independentom. [...] widział siebie jako osobę żyjącą na ziemi, gdzie kwitły niezależne zgromadzenia religijne i dominowały opinie heretyckie; gdzie independenci uniemożliwiali porozumienie z Kościołem państwowym; parlament nie był zainteresowany wsparciem prezbiterian, zaś zwycięskie wojsko całkowicie porzuciło (walkę o) kwestie religijne, które widoczne były regularnie podczas debat pomiędzy frakcjami rozbitego parlamentu ${ }^{37}$.

W takiej rzeczywistości Thomas Edwards postanowił otwarcie zaatakować zepsucie religijne i napiętnować wszelkie znaki herezji, profanacji, zgorszenia. Już sam tytuł pierwszego tomu dzieła wskazuje na cel autora: „Gangrena, czyli katalog i odkrycie licznych błędów, herezji, bluźnierstw, zgubnych praktyk sekciarzy naszych czasów znajdujących ujście i stosowanych w Anglii w ostatnich czterech latach”. Dzieło Edwardsa to swoiste silva rerum różnego rodzaju informacji dotyczących praktyk i wierzeń religijnych w ówczesnej Anglii. Nie jest to książka napisana przez Edwardsa jako monografia czy też systematyczny wykład, a w dużej części jest publikacją setek listów, doniesień i swoistych reportażyków o ludziach bądź grupach oddających się praktykom, które w większości przypadków były modyfikowaną lub zmienioną wersją wierzeń, życia kościelnego i rytuałów chrześcijańskich. Ponadto książka jest zbiorem, niekiedy obrzydliwych, donosów na osoby uprawiające owe praktyki. Przy tym donosy owe najczęściej nie pozostają anonimowe, a Edwards skrupulatnie podaje źródła swoich informacji. Znajdziemy tam liczne informacje „życzliwych”, jak np.:

Mój Panie, wydaje mi się słuszne, abyś wiedział, że ubiegłej soboty ponownie celebrowano żydowski szabat, przy zamkniętych oknach. Ponadto poinformowano mnie o podobnych praktykach w innych częściach miasta $[\ldots]^{38}$.

Czy też:

Jest pewien Pan Erbury, który mieszkał w Walii, a gdy wybrano nowy parlament stał się independentem, lecz od tego czasu stoczył się w otchłań wielu potężnych błędów, twierdząc, iż będzie powszechne zbawienie etc., a obecnie jest poszukiwaczem (Seeker), a nawet sam nie wiem $\operatorname{kim}[\ldots]^{39}$.

Opisów takich są setki - świadczą one o panujących podówczas zjawiskach i sytuacji w sferze religijnej w Anglii.

\footnotetext{
37 P.R.S. B aker, op. cit.

38 Th. Edwards, Gangraena or a Catalogue and Discovery..., s. 95.

39 Ibidem, s. 109. Seekers to jedna z radykalnych sekt ówczesnej Anglii.
} 
Poza przytaczaniem owych donosów/listów autor stworzył w swojej publikacji katalog błędów i herezji, o których wiedział, o których został poinformowany przez osoby zaniepokojone sytuacją lub też które sam odkrył. Katalog ów w pierwszym tomie dzieła liczy 176 błędów i herezji ${ }^{40}$. W tomach drugim i trzecim, które są uzupełnieniem tomu pierwszego, Edwards uzupełnia listę owych błędów, dodając odpowiednio dalsze 23 i 53 błędy ${ }^{41}$. Są to informacje różnej natury - od kwestii teologicznych, doktrynalnych, przez specyficzne zwyczaje i zachowania, przemyślenia filozoficzno-religijne i różne inne, czasem trudne do sklasyfikowania pomysły. Próba ich kategoryzacji i wyciągania na ich podstawie poważnych wniosków jest prawie niemożliwa ${ }^{42}$. Co ważniejsze - katalog ten nie posiada znaczenia i sensu naukowego czy poznawczego. Jest to informacja pokazująca, iż takie właśnie koncepcje i pomysły „mogły” pojawiać się w ówczesnej Anglii, ale nie musiały. Nie wiemy również, gdzie i w jakim okresie poglądy te były głoszone, jakich i ilu miały odbiorców ani jakie mogły być konsekwencje ich przyjęcia. Ich istnienie pozwala wszak autorowi na rozpoznanie tych właśnie poglądów jako swoistych bakterii gnilnych na zdrowym ciele ludu bożego, które zarazem doprowadzają do zepsucia moralnego i upadku. Zaiste nazwa "gangrena" pasuje tu do sytuacji.

Jak duże było to zjawisko? Autor niniejszych słów opiera się na bardzo specyficznych przekazach, czyli literaturze propagandowej, jak również takiej, która miała przekonywać obywateli do jakiejś aktywności - już to w obronie prawdziwej wiary, już to przeciw spodziewanym atakom papistów, już to w celu dokończenia reformacji Kościoła angielskiego. Bliższe badania sytuacji w Londynie wskazują, iż okres ten zaiste charakteryzuje się rozprężeniem religijnym. Jest ono zależne od okresu, o którym mówimy, i jest stosunkowo niewielkie w 1640 r., aby ulec zwiększeniu w chwili wybuchu powstania w Irlandii i wzrastać przynajmniej do chwili oczyszczenia parlamentu czy też ścięcia króla ${ }^{43}$. Najbardziej obawiano się papistów i ich spisków, co autor monografii Londynu w owych czasach tłumaczy faktem, iż było ich tak wielu w samym mieście, że mogli samodzielnie przeprowadzić jakąś demonstrację czy zamach. Pamiętajmy, iż w pamięci wielu obywateli pozostała świadomość planowanego katolickiego zamachu prochowego z 1605 r. W nieco późniejszym czasie strach i swoista nienawiść skoncentrowane były na rojalistach i wojnie z nimi. Około 1642 r. znikają broszurki informujące o odkrytych spiskach przeciw parlamentowi, miastu czy po prostu obywatelom.

Jeżeli chodzi o sekty i radykalne grupy religijne, w latach 1640-1641 było ich niewiele ${ }^{44}$ i były bardzo nieliczne. Jednak z upływem czasu sytuacja uległa zmianie i dla okresu 16411642 autor pisze o potwierdzonych siedmiu grupach separatystów na przedmieściach

40 Ibidem, The Catalogue of Errors, Heresies, Blasphemies, s. 18-36.

${ }_{41}$ Th. Edward s, The Second Part of Gangraena..., s. 1-3; id e m, The Third Part of Gangraena..., s. 2-17.

42 Pełny katalog owych błędów i herezji, w ich tłumaczeniu na język polski, zamieściłem w swojej książce: J. B a sist a, Propaganda religijna..., s. 239-252.

43 K. Lindle y, Popular Politics and Religion in Civil War London, Hants 1997, s. 74-91.

44 Ibidem, s. 79. Za Edwardsem autor podaje, iż byly to „no considerable party”, „so small and inconsiderable party". 
Londynu. Oznacza to, iż ich istnienie zaowocowało powstaniem jakichś źródeł - często policyjnych. Zaś sama nazwa - „separatyści” - nie znaczy dokładnie nic, poza faktem, iż ludzie ci nie utożsamiali się z Kościołem anglikańskim. Liczebność tych grup wahała się od kilku do ponad 70 osób i wśród uczestników spotkań wymieniani byli z imienia i nazwiska mieszkańcy Londynu - bynajmniej nie bezdomni, żebracy czy też „ludzie luźni”, lecz rzemieślnicy i kupcy. Były również kobiety, aczkolwiek nieliczne ${ }^{45}$. Istnienie owych zgromadzeń było niekiedy przyczyną atakowania ich przez innych obywateli i nie można tu wykluczyć sytuacji, w której owi atakujący kierowali się emocjami wywołanymi lekturą różnych pism propagandowych. Poniekąd osobną kwestią były próby nauczania czy prawienia kazań przez osoby nieprzygotowane, to znaczy przez zwykłych obywateli bez jakiegokolwiek wykształcenia teologicznego. Były one zwalczane przede wszystkim przez independentów, którzy dążyli do zachowania wspólnego, zwartego frontu przeciw Kościołowi angielskiemu ${ }^{46}$, który w szczególności po aresztowaniu biskupów utożsamiano z dworem królewskim. Osoby te wzywane były do zeznawania przed parlamentem. Skrajnym przypadkiem było głoszenie kazań przez kobiety - według Lindleya do takiego bluźnierstwa doszło w 1641 r., kiedy to kazania głosiło sześć kobiet ${ }^{47}$, które podane są z imion i nazwisk.

Największy niepokój i strach występowały w Londynie. Historycy badający inne rejony Anglii zwracają niekiedy uwagę, iż w niektórych hrabstwach można było w ogóle nie dostrzec napięcia, a od 1642 r. nie zawsze zdawano sobie sprawę z toczonej wojny domowej. Nie ulega jednak wątpliwości, iż w samym Londynie zapanowała swoista gangrena w kwestiach religijnych. Była ona napędzana brakiem skutecznej kontroli, strachem oraz celową stymulacją rozpowszechnianą propagandą. Całość nasiliła się w chwili opuszczenia Londynu przez Karola I i po rozpoczęciu działań wojennych. Parlament musiał tworzyć własne stronnictwo przeciw rojalistom, a najbardziej skuteczny wydawał się strach.

Wróćmy do początku kryzysu. Zwołany pod koniec roku 1640 Długi Parlament podjął szereg kroków mających na celu ochronę swojego istnienia (akt o nierozwiązywalności, akt o konieczności zwoływania izby co najmniej raz na trzy lata), ale również działania mające ograniczyć władzę episkopatu angielskiego. Kilkunastu biskupów z arcybiskupem Williamem Laudem trafiło do Tower, zaś parlament zaproponował uchwalenie Root and Branch Petition. Była to petycja podpisana rzekomo przez 15 tys. obywateli i skierowana do parlamentu 11 grudnia 1640 r. W petycji domagano się likwidacji Kościoła anglikańskiego w całości (tzn. z korzeniami i gałęziami - stąd „Root and Branch”) ${ }^{48}$. Posłowie nie-

45 Ibidem, s. 80-81. Informacje pochodzą często z petycji kierowanych przez uczestników zgromadzeń do Izby Lordów lub parlamentu. Czasem są to rejestry policji.

46. Ibidem, s. 85-87.

47 Ibidem, s. 87-88. Autor opiera się na drukowanej broszurce, a więc nieco wątpliwym źródle, ale fakt opisu tego zjawiska jest znaczący sam w sobie.

48 Documents Illustrative of English Church History, red. H. Ge e, W.J. Hard y, New York 1896, s. 537-545 (korzystałem z wersji online: https://history.hanover.edu/texts/ENGref/er97.html; dostęp: 14 V 2018). 
zbyt byli chętni, aby postępować tak radykalnie, stąd petycja trafiła pod obrady dopiero w maju 1641 r., a odrzucona została w grudniu tegoż roku. Niemniej jednak w grudniu uchwalony został akt o wykluczeniu biskupów z Izby Lordów ${ }^{49}$. W parlamencie zwyciężyła grupa prezbiterian, a coraz mocniejsi byli jeszcze bardziej radykalni posłowie (np. independenci). Tym samym parlament stworzył warunki do szerokiej działalności wydawniczej, która była mu potrzebna do tworzenia własnego stronnictwa, ale również do podejmowania radykalnych i niekonwencjonalnych kroków przez dysydentów religijnych, purytanów, separatystów, ale również zwykłych obywateli.

Równolegle z usunięciem biskupów rozpoczęto „oczyszczanie” parafii w Londynie z zabobonów i obiektów kultu katolickiego. Dnia 24 kwietnia 1643 r. powstała specjalna komisja mająca dopilnować obalenia zabobonów $\left(\right.$ superstition $\left.^{50}\right)$. Tym samym tworzono jeszcze większą przestrzeń do samodzielnych działań religijnych. Wszak celem wszelkich komisji były przede wszystkim formalne, istniejące struktury parafialne. Sekty adamitów, rodziny miłości, brownistów i innych grup religijnych bądź pseudoreligijnych nie posiadały ani parafii, ani struktur.

Cztery lata później w ramach walki z Kościołem anglikańskim - kościołem Karola I i Williama Lauda - parlament zadecydował o usunięciu Book of Common Prayer ${ }^{51}$ i zastąpieniu owej księgi nabożeństw instrukcją The Directory for Public Worship ${ }^{52}$. Zmiany te oznaczały formalną radykalizację kościoła państwowego w duchu prezbiteriańskim, zaś całość dopełniło uchwalenie tzw. Westminsterskiego Wyznania Wiary, które przygotowane zostało w Londynie, natomiast zatwierdzane osobno w Szkocji i w Anglii. W Szkocji owo wyznanie wiary zostało zatwierdzone przez Zgromadzenie Generalne Kościoła dnia 27 sierpnia 1647 r., natomiast w Anglii parlament na sesji dnia 20 czerwca 1648 r..$^{53}$

49 Charles I, 1640: An Act for disinabling all persons in Holy Orders to exercise any temporall jurisdicc[i]on or authoritie, [w:] Statutes of the Realm, t. V: 1628-80, red. J. Ra ith by (s.l. 1819), s. 138, British History Online, www.british-history.ac.uk/statutes-realm/vol5/p138 (dostęp: 14 V 2018).

50 K. Lindley, op. cit., s. 256-303 dosyć dokładnie opisuje czyszczenie parafii w Londynie, łącznie z usuwaniem niektórych pastorów, niszczeniem szat i sprzętów liturgicznych.

51 January 1645: An Ordinance for taking away the Book of Common Prayer, and for establishing and putting in execution of the Directory for the publique worship of God, [w:] Acts and Ordinances of the Interregnum, 1642-1660, red. C.H. Fir th, R.S. R a it (London 1911), s. 582-607, British History Online, www.britishhistory.ac.uk/no-series/acts-ordinances-interregnum/pp582-607 (dostęp: 14 V 2018); J. B a sista, The Abolishing of the Book of Common Prayer, [w:] Miscellanea Res Polonorum, Brittanorum ac Judaeorum Illustrantia, red. J. Basista, A. Kaźm ierczyk, M. Markiewicz, D. Oliwa, Kraków 2015, s. 201-210.

52 Tekst był załączony jako aneks do aktu usuwającego Book of Common Prayer, a obecnie jest dostępny bez większych problemów np. na stronie Center for Reformed Theology and Apologies: www.reformed. org/documents/wcf_standards/index.html?mainframe=/documents/wcf_standards/p369-direct_pub_ worship.html (dostęp: 14V 2018).

53 W.E. B u r n s, Westminster Confession, [w:] Milestone Documents of World Religions, red. D.M. Fa h e y, t. III, Dallas 2011, s. 1015-1031. Tekst jest dostępny online: https://archive.org/details/humbleadviceofas00west (dostęp: 14V 2018). 
Zarówno likwidacja Book of Common Prayer, jak i usunięcie biskupów i wreszcie uchwalenie nowego wyznania wiary wypełniały postulaty wielu Anglików, w szczególności tych, którzy uważali reformację w Anglii za niedokończoną. Mowa tu o purytanach, jak i prezbiterianach, którzy - obok wprowadzenia rozwiązań zbieżnych z kalwinizmem pragnęli pozbycia się hierarchii wraz z biskupami, prałatami i całym aparatem kościelnym. Jednakże właśnie ten sukces, osiągnięty w kilku krokach i na przestrzeni kilku lat, tworzył, a następnie poszerzał sferę wolności religijnej i brak kontroli nad nią. Warunki wymarzone do powstawania nowych grup religijnych, sekt, stowarzyszeń. Zajęty organizacją oporu wobec rojalistów i konstrukcją własnej milicji, a następnie armii parlament nie był w stanie wprowadzić efektywnej kontroli życia religijnego - przynajmniej nie w początkowej fazie wojny domowej, która wybuchła w 1642 r. Sytuacja ulegnie pewnej zmianie, gdy po ścięciu Karola I i ogłoszeniu republiki dyktatorską władzę objął Oliver Cromwell. Sytuację wewnętrzną w dużej mierze miało kontrolować wojsko.

To, czy zmiany wprowadzone przez parlament i Protektorat rzeczywiście zastopowały mnożenie się sekt i rozszerzanie herezji, trudno jest stwierdzić z pewnością. Okres, w którym w królestwach na Wyspach Brytyjskich o większości spraw decydowało wojsko, na pewno nie sprzyjał demonstracjom religijnym, ale również wszelkiego rodzaju uroczystościom tego typu. Nie istniał jednak i nie został zbudowany sprawny aparat administracyjny, który mógł wymuszać na ludności podejmowanie niepopularnych decyzji czy podporządkowanie niechcianym dekretom. Oliver Cromwell i kadłubowy, skrajnie radykalny parlament kontrolowali sytuację i potrafili wymusić posłuszeństwo, ale nie przychylność i współpracę poddanych. Wraz ze śmiercią Cromwella i krótkim panowaniem jego syna Thomasa w Anglii, a właściwie na Wyspach, powstała pewna próżnia władzy. Porządku pilnowało wojsko, podzielone na kilka terytorialnych jednostek. Sytuacja zmieniła się wraz z samorozwiązaniem szczątkowego Długiego Parlamentu, restauracją Stuartów w 1660 r. i wstąpieniem Karola II Stuarta na tron, wyborem nowego parlamentu i powstaniem nowego, królewskiego rządu.

Jak się wydaje, w całym tym okresie nadal mamy do czynienia ze swoistą gangreną religijną. Dowolność, różnorodność, brak kontroli są zapewne mniejsze niż w czasie wojen z Karolem I, a nie zdarzyło się nic istotnego mogącego zmienić istniejącą sytuację. Swoista dyktatura Cromwella nie utworzyła administracji państwowej, która mogłaby zająć się kwestiami religijnymi. Tym samym po roku 1660 przed nowym rządem, nowym monarchą i nowym parlamentem stał m.in. problem likwidacji owej gangreny w sferze religijnej królestwa.

Patrząc na działania Karola II w sferze religijnej po restauracji, można wyraźnie zobaczyć ostrze skierowane przeciw wszelakim herezjom, sektom, ale również przeciw purytanom, prezbiterianom, jak również katolikom. Rzecz jasna to nie monarcha narzucał ton i formułę owych działań, przyjętych uchwał i wydawanych zarządzen' ${ }^{54}$. Byli to przedstawiciele Kościoła

54 W szczególności trudno sobie wyobrazić Karola II występującego przeciw katolikom. Sam król formalnie był członkiem, a zarazem zwierzchnikiem Kościoła anglikańskiego, ale wiadomo, iż był ściśle związany 
anglikańskiego, którzy zamierzali odbudować sferę religijną sprzed roku 1640. Można by rzec, iż rozpoczęto poszukiwanie lekarstwa, swoistego remedium na panującą gangrenę.

Zastosowane rozwiązanie składało się z kilku elementów. Przede wszystkim powrócono do państwowego Kościoła anglikańskiego w jego elżbietańskim wydaniu. Sam monarcha „przywiózł” ze sobą z wygnania kontynentalnego nominację dla Williama Juxona na arcybiskupa Canterbury. William Juxon był ostatnim duchownym (biskupem) Kościoła anglikańskiego, który towarzyszył ojcu nowego króla, Karolowi I, w drodze na szafot. Później pozbawiony został godności biskupa przez Olivera Cromwella, natomiast po restauracji i w nowej funkcji rekonstruował struktury kościelne oraz episkopat wraz z królem Karolem II ${ }^{55}$. W 1662 r. ponownie wprowadzono Book of Common Prayer w wersji jedynie w niewielu szczegółach różniącej się od księgi elżbietańskiej. Tak The Directory for Public Worship, jak i Westminsterskie Wyznanie Wiary zostały obalone i zakazane.

W celu zdyscyplinowania poddanych i wywarcia na nich presji (religijnej) wprowadzony został tzw. kodeks Clarendona ${ }^{56}$. Kodeks ów oraz uchwalony dodatkowo w 1673 r. Test act ${ }^{57}$ można uznać za akty wykonawcze, mające przyczynić się do oczyszczenia administracji państwowej z rekuzantów (recusant - tak nazywano osoby odmawiające przyjęcia sakramentu komunii w Kościele anglikańskim). Każdy urzędnik miał obowiązek złożenia przysięgi na wierności monarsze (wszak monarcha był zwierzchnikiem Kościoła) i zaprzeczenia transsubstancjacji (szczególnie ważne w przypadki osób podejrzewanych o katolicyzm). Co ciekawe, akt z 1673 r. wyłączał spod owego prawa członków Izby Lordów. Dlatego też pięć lat później, w 1678 r., Test act ${ }^{58}$ został rozszerzony na członków izby wyższej. Oba akty, jak i akt o korporacjach, któremu poświęcimy kilka słów niżej, na pewno skierowane były przeciwko sekciarzom, a przede wszystkim uderzały w katolików.

Kodeks Clarendona otrzymał swoją popularną nazwę, używaną po dziś dzień, od kanclerza Karola II, Edwarda Hyde’a, pierwszego earla Clarendon, który był najwyższym urzędnikiem królewskim ${ }^{59}$. Nieistotny jest fakt, iż sam minister nie miał z owym kodeksem nic

z katolicyzmem i najprawdopodobniej zmienił wyznanie przed śmiercią. Jego brat i następca, Jakub II, zawsze deklarował swój katolicyzm. Niemniej jednak obaj byli przeciwni różnorodnym sektom i herezjom.

55 www.britannica.com/biography/William-Juxon (dostęp: 15 V 2018).

56 Cociekawe, wielu historyków traktujeów kodeks Clarendonajako skierowany przeciwko nonkonformistom i ewentualnie katolikom. Wydaje się, iż spojrzenie na owe rozwiązania przez pryzmat Gangraeny Edwardsa i owego rozpasania religijnego, licznych sekt i herezji dobitniej wyjaśnia, skąd takie właśnie rozwiązania. O nonkonformistach zob. np. H. Z in s, Historia Anglii, Wrocław-Warszawa-Kraków 1995, s. 208-209.

57 Charles II, 1672: An Act for preventing Dangers which may happen from Popish Recusants, [w:] Statutes of the Realm, t. 5, s. 782-785, British History Online, www.british-history.ac.uk/statutes-realm/vol5/pp782785 (dostęp: 26 IV 2018).

58 Charles II, 1678: (Stat. 2.) An Act for the more effectuall preserving the Kings Person and Government by disableing Papists from sitting in either House of Parlyament, [w:] Statutes of the Realm, t. V, s. 894-896, British History Online, www.british-history.ac.uk/statutes-realm/vol5/pp894-896 (dostęp: 26 IV 2018).

59 P. Se aw ard, Hyde, Edward, first earl of Clarendon (1609-1674), [w:] Oxford Dictionary of National 
wspólnego - ani nie był jego inicjatorem, ani twórcą. Kodeks powstał w parlamencie, który był niezwykle rojalistyczny, a w kwestiach religijnych bliższy Kościołowi anglikańskiemu niżby widział to sam Karol II. To właśnie posłowie z energią zabrali się do porządkowania kwestii religijnych czy też wprowadzenia remedium na ową gangrenę, która od dwóch dekad niszczyła prawdziwą - ich zdaniem - religię. Sam kodeks to zbiór czterech uchwał parlamentu zatwierdzonych przez monarchę, które uchwalone zostały w latach 1661-1665, a których celem było utwierdzenie pozycji Kościoła anglikańskiego, przy równoczesnym wyeliminowaniu grup heretyckich, sekt, odszczepieńców od prawdziwej wiary. Pośród podmiotów, przeciwko którym skierowany był kodeks, wysoko na liście znajdował się Kościół katolicki.

Jako pierwszy w 1661 r. został uchwalony akt o korporacjach ${ }^{60}$. Celem nowo uchwalonego prawa było ograniczenie możliwości sprawowania wszelkich urzędów państwowych wyłącznie do członków Kościoła anglikańskiego. Według uchwalonego prawa w administracji państwowej i korporacjach mogły zasiadać jedynie te osoby, które w poprzedzających 12 miesiącach przyjmowały sakrament Wieczerzy Pańskiej według rytu Kościoła anglikańskiego, a więc w praktyce według zasad określonych w Book of Common Prayer oraz innych dokumentów tegoż Kościoła. Ponadto wymagał on od tych samych osób złożenia dwóch przysiąg: na wierność monarsze ${ }^{61}$ jako głowie Kościoła oraz przysięgi odrzucającej wiarę w transsubstancjację. Formalnie akt ten został uchylony dopiero w 1828 r. wraz z przywróceniem praw katolikom.

Drugą część kodeksu Clarendona stanowił uchwalony przez parlament w 1662 r. akt o ujednoliceniu religijnym (Act of Uniformity) ${ }^{62}$. Akt ten przede wszystkim wprowadzał wszystkie zasady funkcjonowania Kościoła opisane w Book of Common Prayer. Księga owa - będąca zbiorem modlitw, zasad, założeń dotyczących świąt, rytuałów i w ogóle funkcjonowania Kościoła - została w niektórych szczegółach zmieniona w stosunku do wersji z czasów królowej Elżbiety. Na przykład pojawiła się lista dni, w które należało pościć. Nie zmienia to faktu, iż w doktrynie religijnej nic nie zostało zmienione. Kościół Karola II miał być kontynuacją Kościoła Elżbiety I, a obowiązkową księgą wyznaczającą zasady jego funkcjonowania ponownie była Book of Common Prayer. Tak jest zresztą po dziś dzień.

Biography, https://doi.org/10.1093/ref:odnb/14328.

60 Charles II, 1661: An Act for the well Governing and Regulating of Corporations, [w:] Statutes of the Realm, t. V, s. 321-323, British History Online, www.british-history.ac.uk/statutes-realm/vol5/pp321-323 (dostęp: 16 V 2018).

${ }^{61}$ Chodzi o taką samą przysięgę, za odmowę złożenia której ścięci zostali Thomas Morus oraz John Fisher, a także wielu innych obywateli niegodzących się na odłączenie od Rzymu za czasów Henryka VIII.

62 Charles II, 1662: An Act for the Uniformity of Publique Prayers and Administrac [i]on of Sacraments \& other Rites \& Ceremonies and for establishing the Form of making ordaining and consecrating Bishops Preists and Deacons in the Church of England, [w:] Statutes of the Realm, t. V, s. 364-370, British History Online, www. british-history.ac.uk/statutes-realm/vol5/pp364-370 (dostęp: 16 V 2018). 
Jako trzeci uchwalony został w 1664 r. akt o konwentyklach ${ }^{63}$, a konkretnie akt o zapobieganiu i usunięciu buntowniczych konwentykli, czyli zgromadzeń religijnych. Ustanowione prawo zakazywało - pod groźbą różnych kar - organizowania zgromadzeń religijnych poza Kościołem państwowym. Kary pieniężne za niestosowanie się do ustawy sięgały nawet 100 funtów, ale również przewidziane były kary aresztu prewencyjnego do czasu najbliższych posiedzeń sądów, które mogły rozpatrywać winę danej osoby. Lokalni urzędnicy zobowiązani byli do zapobiegania zebraniom religijnym, a właściciele budynków, w których spotkania się odbywały, musieli liczyć się z wysoką karą finansową, a także więzieniem.

Prawo precyzowało, w jakich okolicznościach można było dokonać rewizji domostw podejrzanych o to, iż odbywały się w nich zgromadzenia religijne. Gdyby takowe miały miejsce w Londynie, w domu któregoś deputowanego (Peer), rewizja miała odbyć się na wyraźny rozkaz króla w obecności co najmniej dwóch sędziów pokoju lub innych urzędników (co zostało dokładnie określone).

Osobny artykuł został poświęcony kwakrom i tym sekciarzom, którzy odmawiali składania zwykłej przysięgi w sądzie, zasłaniając się własnymi przekonaniami.

Akt ten miał oczywiście zminimalizować istnienie różnych sekt i usunąć je z życia publicznego. W 1689 r. został anulowany, chociaż już wcześniej niektóre jego paragrafy zostały nieco złagodzone przez Karola II wraz z nadaniem Royal Declaration of Indulgence w $1672 \mathrm{r}^{64}$

Rok po uchwaleniu aktu o konwentyklach królowi przedstawiono do podpisania ostatni z aktów tworzących kodeks Clarendona, czyli akt o pięciu milach ${ }^{65}$. Prawo owo zakazywało osobom, które głosiły kazania i uczyły w owych kongregacjach, sektach, konwentyklach i wszelkiego rodzaju grupach religijnych, zbliżania się na odległość mniejszą niż pięć mil do miejscowości, z których wybierani byli posłowie do parlamentu, a w których funkcjonowały uprzednio jakiekolwiek grupy religijne, sekciarskie czy heretyckie. Osoby takie mogły obok rzeczonych miejsc przejść lub przejechać, ale nie wolno im się było w nich zatrzymywać pod karą grzywny, a następnie więzienia. Co więcej, wszystkie rzeczone osoby miały całkowity zakaz nauczania we wszelkich szkołach w królestwie.

Prawo to oznaczało konieczność złożenia przysięgi wierność królowi, jak również Kościołowi angielskiemu (ponownie przysięga odrzucająca transsubstancjację), lub

63 Charles II, 1664: An Act to prevent and suppresse seditious Conventicles, [w:] Statutes of the Realm, t. V, s. 516-520, British History Online, www.british-history.ac.uk/statutes-realm/vol5/pp516-520 (dostęp: 23 IV 2018). Kolejne akapity powstały w oparciu o cytowany tekst.

64 Karol II nigdy nie był nastawiony skrajnie negatywnie wobec dysydentów ani katolików, a tym ostatnim wręcz sprzyjał. Dlatego też dopuścił kult w prywatnych kaplicach (np. dla katolików). Rzecz jasna spotkało się to z krytyką posłów i doprowadziło do kryzysu, a w dalszej konsekwencji do powstania stronnictw wigów i torysów, ale to temat na inny artykuł.

65 Charles II, 1665: An Act for restraining Non-Conformists from inhabiting in Corporations, [w:] Statutes of the Realm, t. V, s. 575, British History Online, www.british-history.ac.uk/statutes-realm/vol5/p575 (dostęp: 23 IV 2018). Opis ustaleń pochodzi z tego dokumentu. Prawo to również bywa nazywane aktem oksfordzkim czy też aktem o nonkonformistach z roku 1665. 
opuszczenie miejsca zamieszkania, co najczęściej wiązało się z koniecznością udania się w inne rejony kraju bądź za granicę i to najczęściej bez jakiegokolwiek wsparcia finansowego. Nie jest znana liczba osób bezpośrednio dotkniętych owym aktem, ale można znaleźć stwierdzenia, iż „tysiące duchownych” straciło możliwość zarabiania i dach nad głową.

Akt o pięciu milach został odwołany przez parlament dopiero w 1828 r. wraz z uchwaleniem Sacramental Test Act ${ }^{66}$, który m.in. anulował obowiązującą w Anglii konieczność przyjmowania komunii w Kościele anglikańskim przez wszystkich urzędników państwowych.

Wiemy doskonale, iż Karol II był uważany za kryptokatolika. Uważa się, iż w chwili śmierci był już katolikiem, a jego brat i następca nigdy nie krył się ze swoim katolicyzmem. Wprowadzone przez parlament akty uderzały w katolików, wykluczając ich z życia publicznego. Wydaje się jednak, iż nie chodziło tutaj li tylko o katolików i skłonności ku temu wyznaniu rodziny królewskiej. Kościół katolicki i jego członkowie to nie konwentykle, to nie potajemne zgromadzenia w prywatnych domach, choć i takie miały miejsce. Owe zwalczane grupy to pozostałości po tych dawnych, aktywnych w latach kryzysu 1640-1660. Kodeks Clarendona skierowany był przeciw prezbiterianom, przeciw independentom, przeciw kwakrom, przeciw separatystom i wszystkim grupom religijnym, które dzięki kryzysowi Kościoła instytucjonalnego uzyskały możliwość działania. Powiązanie kwestii religijnych ze sprawami państwowymi stawiało osoby spoza Kościoła anglikańskiego przed niezwykle trudnym dylematem. Jeśli chciały normalnie żyć i funkcjonować, nie wspominając o możliwości piastowania urzędów państwowych, musiały wyrzec się swojej herezji i przyjąć komunię w Kościele anglikańskim Kościele państwowym. Przy okazji liczne rykoszety trafiały w katolików.

Jeżeli na początku lat czterdziestych wieku XVII zdiagnozujemy w Anglii swoistą gangrenę religijną, to bez wątpienia kodeks Clarendona i okołokodeksowe ustawy (Test acts) stanowiły swoiste remedium na ową chorobę - albo leczyły odszczepieńców z ich ideologii, albo skutecznie amputowały chorą tkankę. Na pewno było to remedium skuteczniejsze niż wprowadzane przez parlament w latach czterdziestych, a następnie przez Cromwella w czasie republiki i protektoratu. Co więcej - wiemy, iż w dużej mierze remedium to okazało się skuteczne.

\section{BIBLIOGRAFIA}

Źródła:

A description of the sect called the Family of Love, London 1641.

A Dialogue betwixt three travellers, London 1641.

A Discovery of 29 sects here in London, all of which except the first, are most divelish and damnable, London 1641.

66 R.A. Gaunt, Peel's Other Repeal: The Test and Corporation Acts, 1828, „Parliamentary History” 2014, t. 33, z. 1, s. 243-262, https://doi.org/10.1111/1750-0206.12096. 
Burns W.E., Westminster Confession, [w:] Milestone Documents of World Religions, red. D.M. Fahey, t. III, Dallas 2011, s. 1015-1031, https://archive.org/details/humbleadviceofas00west.

Charles I, 1640: An Act for disinabling all persons in Holy Orders to exercise any temporall jurisdicc [i] on or authoritie, [w:] Statutes of the Realm, t. V: 1628-80, red. J. Raithby, (s.l, 1819), s. 138, British History Online, www.british-history.ac.uk/statutes-realm/vol5/p138.

Charles II, 1661: An Act for the well Governing and Regulating of Corporations, [w:] Statutes of the Realm, t. V: 1628-80, red. J. Raithby (s.l. 1819), s. 321-323, British History Online, www.british-history.ac.uk/statutes-realm/vol5/pp321-323.

Charles II, 1662: An Act for the Uniformity of Publique Prayers and Administrac[i]on of Sacraments \& other Rites \& Ceremonies and for establishing the Form of making ordaining and consecrating Bishops Preists and Deacons in the Church of England, [w:] Statutes of the Realm, t. V: 162880, red. J. Raithby (s.l. 1819), s. 364-370, British History Online, www.british-history.ac.uk/ statutes-realm/vol5/pp364-370.

Charles II, 1664: An Act to prevent and suppresse seditious Conventicles, [w:] Statutes of the Realm, t. V: 1628-80, red. J. Raithby (s.l. 1819), s. 516-520, British History Online, www.british-history. ac.uk/statutes-realm/vol5/pp516-52.

Charles II, 1665: An Act for restraining Non-Conformists from inhabiting in Corporations, [w:] Statutes of the Realm, t. V: 1628-80, red. J. Raithby (s.l. 1819), s. 575, British History Online, www. british-history.ac.uk/statutes-realm/vol5/p575.

Charles II, 1672: An Act for preventing Dangers which may happen from Popish Recusants, [w:] Statutes of the Realm, t. V: 1628-80, red. J. Raithby (s.l. 1819), s. 782-785, British History Online, www.british-history.ac.uk/statutes-realm/vol5/pp782-785.

Charles II, 1678: (Stat. 2.) An Act for the more effectuall preserving the Kings Person and Government by disableing Papists from sitting in either House of Parlyament, [w:] Statutes of the Realm, t. V: 1628-80, red. J. Raithby (s.l. 1819), s. 894-896, British History Online, www.british-history. ac.uk/statutes-realm/vol5/pp894-896.

Cheynell F., The Rise, Growth and Danger of Socinianisme, London 1643.

Edwards Th., Gangraena, or a Catalogue and Discovery of many of the Errours, Heresies, Blasphemies and pernicious Practices of the Sectaries of this time, vented and acted in England in these four last yeers, London 1646.

Edwards Th., The Second Part of Gangraena, or A fresh and further Discovery of many of the Errors, Heresies, Blasphemies and pernicious Practices of the Sectaries of this time, vented and acted in England in these four last yeers, London 1646.

Edwards Th., The third part of Gangraena. Or, A new and higher discovery of the errors, heresies, blasphemies, and insolent proceedings of the sectaries of these times; with some animadversions by way of confutation upon many of the errors and heresies named, London 1646.

January 1645: An Ordinance for taking away the Book of Common Prayer, and for establishing and putting in execution of the Directory for the publique worship of God, [w:] Acts and Ordinances of the Interregnum, 1642-1660, red. C.H. Firth, R.S. Rait (London, 1911), s. 582-607, British History Online, www.british-history.ac.uk/no-series/acts-ordinances-interregnum/pp582-607.

Pagitt E., Christionography, or the description of the multitude and sundry sorts of Christians in the world, not subject to the pope, London 1640.

Pagitt E., Heresiography, or a Description of the Heretickes and Sectaries sprung up in this latter times, London 1645.

Religions Lotterie or the Churches Amazement, London 1642.

Sedgwick J., Antynomianisme anatomized, London 1643. 
Taylor J., A Cluster of Coxcombes, or a cinquepace of five sorts of Knaves and Fools, London 1942.

The Remarkable Funeral of Cheapside Cross, London 1642.

Yarb S., A new Sect of Religion descryed called Adamites, London 1643.

\section{Opracowania:}

Baker P.R.S., Edwards, Thomas, [w:] Oxford Dictionary of National Biography, www.oxforddnb. $\mathrm{com} / \mathrm{view} / 10.1093 / \mathrm{ref}:$ odnb/9780198614128.001.0001/odnb-9780198614128-e-8556.

Basista J., Anglia i Szkocja między uniami (1603-1707), [w:] Europa unii i federacji, red. K. Ślusarek, Kraków 2004, s. 131-140.

Basista J., Jakub VI (I) Stuart w angielskiej przestrzeni religijnej, „Studia Europaea Gnesnensia” 2018, t. 18, s. 385-406.

Basista J., Koncepcja wtadzy monarszej Jakuba VI(I), [w:] Spory o państwo w dobie nowożytnej, red. Z. Anusik, Łódź 2007, s. 357-366.

Basista J., Kościót elżbietański: między martyrologia a reformą, [w:] Sic Erat in Fatis. Studia i szkice historyczne dedykowane Profesorowi Bogdanowi Rokowi, red. E. Kościk, R. Żerelik, P. Badyna, F. Wolański, Toruń 2012, s. 272-282.

Basista J., Propaganda religijna w przededniu i pierwszych latach angielskiej wojny domowej, Kraków 2007.

Basista J., Spór wokót arminianizmu. Czy arcybiskup Laud wywotat angielską rewolucję?, [w:] Studia z dziejów kultury i mentalności czasów nowożytnych, red. K. Matwijowski, B. Rok, Wrocław 1993, s. 113-124.

Basista J., The Abolishing of the Book of Common Prayer, [w:] Miscellanea Res Polonorum, Brittanorum ac Judaeorum Illustrantia, red. J. Basista, A. Kaźmierczyk, M. Markiewicz, D. Oliwa, Kraków 2015, s. 201-210.

Documents Illustrative of English Church History, red. H. Gee, W.J. Hardy, New York 1896, s. 537 545, https://history.hanover.edu/texts/ENGref/er97.html.

Gaunt R.A., Peel's Other Repeal: The Test and Corporation Acts, 1828, „Parliamentary History” 2014, t. 33, z. 1, s. 243-262, https://doi.org/10.1111/1750-0206.12096.

Hughes A., Gangraene and the Struggle for the English Revolution, Oxford 2004.

James L., 'This Great Firebrand'. William Laud and Scotland 1617-1645, Woodbridge 2017.

Lindley K., Popular Politics and Religion in Civil War London, Hants 1997.

Milton A., Catholic and Reformed. The Roman and Protestant Churches in English Protestant Thought, 1600-1640, Cambridge 1995.

Morrill J., Revolt in the Provinces: the People of England and the Tragedies of War, 1630-1648, New York Longman 1999.

Peacey J., Politicians and Pamphleteers, Hants 2004.

Peacey J., Print and Public Politics in the English Revolution, Cambridge 2013.

Prior Ch.W.A., Defining the Jacobean Church. The Politics of Religious Controversy, 1603-1625, Cambridge 2005.

Raymond J., Pamphlets and Pamphleteering in Early Modern Britain, Cambridge 2003.

Russell C., The Causes of the English Civil War, Oxford: Clarendon Press 1990.

Seaward P., Hyde, Edward, first earl of Clarendon (1609-1674), [w:] Oxford Dictionary of National Biography, https://doi.org/10.1093/ref:odnb/14328.

Trevor-Roper H., The Fast Sermons of the Long Parliament, [w:] H. Trevor-Roper, The Crisis of the Seventeenth Century, New York 1967, s. 275-276.

Zins H., Historia Anglii, Wrocław-Warszawa-Kraków 1995. 


\section{Strony internetowe:}

https://encyklopedia.pwn.pl/encyklopedia/gangrena.html.

www.reformed.org/documents/wcf_standards/index.html?mainframe=/documents/wcf_standards/p369-direct_pub_worship.html.

www.britannica.com/biography/William-Juxon. 